KS. JAN JÓZEF JANICKI

\title{
INSTAURARE OMNIA IN CHRISTO PAPIEŻA ŚW. PIUSA X (1903-1914) - A ODNOWA LITURGICZNA
}

Wiek XIX stanowił szczególnie trudny czas dla życia Kościoła, który znalazł się pod wpływem bardzo negatywnych dla życia chrześcijańskiego skutków rewolucji francuskiej oraz pod nowym i silnym zagrożeniem dla życia religijnego, jakim stał się rozpowszechniany ateizm i materializm'. Pomimo tego, ten okres dziejów Kościoła stał się wiekiem odnowy, opartej na dokładnym przestrzeganiu tradycji katolickiej według nieomylnego Urzędu Nauczycielskiego Kościoła, według ścisłych norm liturgicznych oraz według duchowości rzymsko-łacińskiej ${ }^{2}$. Wiek ten stał się również czasem odszukiwania ukrytych skarbów, które istniały w Kościele od dawna; dokonywało się to poprzez rozwój nauk historycznych zajmujących się początkami Kościoła, w tym badaniami nad liturgią. Wysiłkom katolickich naukowców towarzyszyła pobożność eucharystyczna, która znajdowała swój wyraz w Kongresach Eucharystycznych i która ogarniała coraz szersze kręgi wierzących ${ }^{3}$.

Pośród różnych działań mających na celu odnowę życia chrześcijańskiego, podejmowanych przez Kościół w XIX i na początku wieku XX, odnowa liturgii zaczęła najbardziej wzbogacać jego życie religijne. W liturgii zaczęto na nowo dostrzegać istotę życia chrześcijańskiego i w niej szukano jego odnowy ${ }^{4}$; „nie tylko nowymi środkami oddziaływania”, ale nadając życiu Kościoła „wyraz tak potrzebnej powagi i dostojeństwa", Przykładowa i klasyczna celebracja liturgiczna w klasztorach (głównie benedyktyńskich) oraz „apostolskie" usiłowania „,wyjścia” $\mathrm{z}$ taka liturgią do wszystkich wiernych stały się rysem charakterystycznym tzw. ruchu liturgicznego ${ }^{6}$.

O ile odnowa liturgiczna po Soborze Watykańskim II, mająca za cel „nieustanne pogłębianie chrześcijańskiego życia wiernych" (KL 1) dokonuje się nieja-

\footnotetext{
'Por. M. B a n a s z a k, Historia Kościota Katolickiego, 3*: Czasy nowożytne 1758-1914, Warszawa 1991, s. 362.

${ }^{2}$ Zob. B. N e u n h e us e r, Sto lat ruchu odnowy liturgicznej zapoczatkowanej przez o. Prospera Guéranger. Przeszlość i perspektywy, RBL 29(1976), s. 198.

${ }^{3}$ Por. tamze.

${ }^{4}$ Por. L. B e a u du i n, Modlitwa Kościola, Kraków 1987, s. 53.

${ }^{5} \mathrm{Z} . \mathrm{Z}$ i e l i ń s k i, Papiestwo i papieże dwóch ostatnich wieków, cz. II, Poznań 1986, s. 16.

${ }^{6}$ Zob. B. N e u n h e u s e r, Sto lat ruchu..., art. cyt., s. 198.
} 
ko „odgórnie” i w całym Kościele, o tyle zwłaszcza druga połowa XIX i pierwsze dekady XX wieku, były dziełem „oddolnym” poszczególnych promotorów, tych, którzy byli liturgiae cultores et amatores oraz takich ośrodków, jak Solesmes, Maria Laach, Mont-César (Louvain), Beuron czy Klosterneuburg.

Pierwszą i najbardziej autorytatywną osobą pokazującą liturgię jako źródło życia duchowego dla każdego chrześcijanina, a nie tylko dla niewielkich „wybranych" grup wiernych, stal się papież Pius $\mathbf{X}^{7}$, ,pasterz dusz”, który programem swojej posługi apostolskiej uczynił hasło: Instaurare omnia in Christo ${ }^{8}$. Przyjęcie tej dewizy oznaczało dla tego papieża odrodzenie społeczeństwa chrześcijańskiego nie tylko poprzez żarliwą obronę praw Chrystusa i Jego Kościoła, lecz również podejmowanie pozytywnego dzieła reform i inicjatyw, „których cel był w zasadzie duszpasterski, a które zmierzały do pogłębienia życia wewnętrznego i lepszego wykorzystania jego zasobów. Pius X zabrał się do tego dzieła z doświadczeniem czterdziestu lat spędzonych $\mathrm{z}$ dala od Kurii Rzymskiej na różnych szczeblach aktywnej posługi duszpasterskiej - z całą jasnością i przedsiębiorczością, której dowody dał kierując diecezjami Mantui i Wenecji"".

${ }^{7} \mathrm{~W}$ pierwszych dniach sierpnia 2003 roku minęła setna rocznica wyboru kard. Giuseppe Melchiorre Sarto na stolicę Piotrowa jako Piusa X, a konklawe, podczas którego doszło do jego wyboru, w sposób szczególny należy do wydarzeń historycznych Kościoła. W czasie bowiem jego trwania po raz ostatni $w$ dziejach papiestwa zastosowano weto, które $w$ imieniu cesarza Austro-Węgier Franciszka Józefa I zgłosił biskup krakowski kardynał Jan Puzyna. Cesarz posłużył się ekskluzywą, aby nie dopuścić do wyboru na papieża kardynała Mariano Rampolla. W Archiwum Kapitulnym na Wawelu ks. prof. Jacek Urban odnalazł nieznane dotąd historykom źródło dotyczące tematyki owego weto: jest nim relacja samego biskupa krakowskiego kard Jana Puzyny, który weto osobiście przedstawił w imieniu cesarza Franciszka Józefa I zob. J. U r b a n, Relacja kard. Jana Puzyny o konklawe 1903 r. i o jego stynnym weto, $\mathrm{FHCr} 8$ (2002), s. 273-276.

${ }^{8}$ Por. Z. Z i e li ń s k i, Papiestwo i papieże..., dz. cyt., s. 10 n.; Autor uważa, iż program papieski zawarty w haśle: Odnowić wszystko w Chrystusie (Instaurare omnia in Christo) ",mylnie odczytywano (...) za zapowiedź reformy, tu chodziło po prostu o urządzanie wszystkiego w Chrystusie, o pozytywne działanie. To było coś znacznie więcej niż reformy. Pius X z góry wykluczył jakiekolwiek kompromisy ze światem, który odchodzi od Chrystusa, zdradzał swoja świadomość nadciagającej ofensywy zła, zeświecczenia. Swoją rolę w obliczu tych zjawisk widział w postaci budowniczego królestwa Bożego wbrew ludzkim względom i rachubom. Nie watpił też ani na chwilę, że zwycięstwo należy do sprawy Bożej. Nie trzeba tylko wahać się, gdy przychodzi demaskować szatana, i nie wolno z nim paktować, zaraz bowiem zatruje on życie społeczne i prywatne. Chrystus jest jedyną zasadą odnowy religijnej, a powrót do niego oznacza rezygnację z nieokiełznanej wolności, której ludzie domagają się dlatego, by móc czynić zło. Papiez więc zapowiada walke z siłami zła, a po to, by móc ja prowadzić, trzeba przede wszystkim usprawnić szeregi duchowieństwa, wyznaczyć mu odpowiednią rolę. Pius X zalecał więc zastosowanie wszelkich środków ku temu podanych przez Sobór Trydencki" - tamże, 11.

${ }^{9} \mathrm{R}$. A u b e r t, Kościót katolicki od kryzysu 1848 roku do pierwszej wojny światowej, [w:] red. L. J. Rogier, R. Aubert, M. D. Knowles, Historia Kościota, 5: 1848 do czasów wspótczesnych, Warszawa 1985, s. 18. Autor uważa, że papież Pius X nie pozwolił się „opanować” biurokracji i dlatego przeprowadził w ciągu krótkiego czasu (jego pontyfikat trwał tylko jedenaście lat) wiele reform, o które dopominano się w Kościele od stuleci, a które w owym czasie uważano także za rewolucyjne. Były to m.in. dekrety dotyczące Komunii św. dzieci i częstego jej przyjmowania przez dorosłych, muzyki kościelnej i liturgii, a ponadto wskazania kierowane do ogółu świeckich, które sprawiły, ze Pius X został uznany za pioniera Akcji Katolickiej - por. tamże. 
Św. Pius X, Papież-Odnowiciel wszystkiego w Jezusie Chrystusie, rozpoczął swój pontyfikat od uroczystego potwierdzenia słuszności rozwijającego się ruchu liturgicznego, iż aby odnowić prawdziwego ducha chrześcijańskiego, trzeba przyprowadzić całą wspólnotę wierzących do pierwszego i nie do zastapienia przez inne formy pobożności źródła tego ducha, a mianowicie do czynnego udziału wiernych w liturgii, określonej przez Piusa X jako świête misteria (tajemnice), a także publiczna i uroczysta modlitwa Kościoła. Papież nauczał: „Jest naszym najgorętszym pragnieniem, aby prawdziwy duch chrześcijański na nowo rozkwitł na wszelki sposób i ogarnął wszystkich wiernych. Jest więc rzeczą konieczną zatroszczyć się przede wszystkim o świętość i godność świątyni, gdzie wiemi się gromadzą właśnie, aby szukać owego ducha chrześcijańskiego w jego pierwszym i niezastappionym źródle, to znaczy w czynnym udziale w Świętych Misteriach oraz w publicznej i uroczystej modlitwie Kościoła"10. Papież Pius X, podejmując się realizacji swego programu „odnowienia wszystkiego w Chrystusie” w dziedzinie liturgii, skoncentrował swe działania przede wszystkim na odnowie śpiewu i muzyki liturgicznej (motu proprio Tra le sollecitudini - z 22 listopada 1903 r.), zachęcie, skierowanej do dorosłych, do częstego, codziennego przyjmowania Komunii św. (dekret Sacra Tridentina Synodus - z 20 grudnia 1905 r.), na dopuszczeniu dzieci do (pierwszej) Komunii św. (dekret Quam singulari Christus amore - z 8 sierpnia $1910 \mathrm{r}$.) oraz na reformie brewiarza czyli officium divinum (,,dzisiejszej" Liturgii godzin - codziennej modlitwy Ludu Bożego) (motu proprio Divino afflatu Spiritu - z 11 listopada 1911 r.) ${ }^{11}$.

\section{ODNOWA SPIEWU I MUZYKI LITURGICZNEJ (1903)}

Święty papież Pius X zaczął odnowę liturgii od odnowy śpiewu i reformy muzyki kościelnej, której bardzo głębokich i skutecznych oddziaływań doświadczył jako patriarcha Wenecji (1893-1903). Z tychże doświadczeń weneckich, z których wiele ten Pasterz przenosił do życia Kościoła powszechnego, narodził się dokument o charakterze motu proprio ${ }^{12}$, noszacy nazwe Tra le sollecitudini (Inter pastoralis officii sollicitudines), zawierający Instrukcję o muzyce kościelnej (Instructio de musica sacra), a wydany dnia 22 listopada 1903 roku, w liturgiczne wspomnienie św. Cecylii, dziewicy i męczennicy, patronki muzyki kościelnej ${ }^{13}$.

${ }^{10}$ Cyt. za: L. B e a u du in, Modlitwa Kościola..., dz. cyt., s. 84; zob. tłumaczenie w: G. M. S u ñ o 1, Zasady śpiewu gregoriańskiego, Poznań 1957, s. 216.

${ }^{11}$ Por. M. R i g h e $t \mathrm{t}$ i, Storia liturgica, I: Introduzione generale, Milano ${ }^{3} 1964$, s. 52; O R o u s s e a u, Storia del movimento liturgico, Roma 1961, s. 239; R. A u b e r t, Das Reformwerk Pius'X. Eucharistische Dekrete und liturgische Erneuerung, [w:] H. Jedin (red.), Die Kirche in der Gegenwart. VI/2. Die Kirche zwischen Anpassung und Widerstand, Freiburg 1985, s. 416-426; R. A u bert, Kościól katolicki od kryzysu..., dz. cyt., s. 7-21; A. H a qu i n, Les décrets eucharistiques de Pie $X$. Entre mouvement eucharistique et mouvement liturgique, LMD 203 (1995), s. 61-82.

${ }^{12}$ Łacińskie określenie: motu proprio czyli: z wlasnej inicjatywy oznacza „wydane przez papieża zarządzenie, niekiedy nawet bez osobliwych formalności" (A. J o u g a n, Stownik kościelny tacińsko-polski, Poznań 1958, s. 433).

${ }^{13} \mathrm{P}$ j u s X, Motu proprio Tra le sollecitudini (22 XI 1903), Wstęp (polskie thumaczenie w: G. M. S u ñ o l, Zasady spiewu..., dz. cyt., 213-226). Por. B. N e u n h e us e r, Sto lat ruchu od- 
We Wstepie do tego dokumentu, określanego jako Ustawa prawomocna o muzyce kościelnej ${ }^{14}$, Pius X napisał, że ,jedną z ważnych trosk urzędu Pasterskiego, nie tylko na tej najwyższej Stolicy Biskupiej, (...), ale i w każdym pojedynczym kościele stanowi zadanie utrzymania i podniesienia uroku Domu Bożego, w którym odbywają się wzniosłe tajemnice religijne i w którym lud wierny się zgromadza, aby dostapić łask sakramentalnych, uczestniczyć w świętej Ofierze Ołtarza, uczcić Przenajświętszy Sakrament Ciała Pańskiego i połączyć się we wspólnej modlitwie, zanoszonej przez Kościół wśród wzniosłych czynności liturgicznych. Nic zatem nie powinno wydarzyć się w świątyni, co by przeszkadzało, lub choćby tylko zmniejszało pobożność i skupienie ducha wiernych; nic, co by stanowiło słuszną przyczynę niesmaku lub zgorszenia, a nade wszystko nic, co by wprost obrażało powagę i świętość kościelnych czynności i tym samym stawało się niegodnym Domu Modlitwy i Majestatu Bożego"15.

Ojciec Święty, kierując do całego Kościoła powszechnego zaraz na początku swego pontyfikatu stosunkowo obszerną i poniekąd surową instrukcję o śpiewie i muzyce kościelnej, uznał, że wymaga tego zaistniała sytuacja nadużyć w tej dziedzinie życia Kościoła. Papież Pius X nie określając szczegółowo owych „nadużyć”, które mogą się wydarzyć, stwierdza, iź chodzi o jedno „z najzwyklejszych i najtrudniejszych do wykorzenienia naduźyć, nad którym trzeba nieraz ubolewać w takich nawet miejscowościach, w których każda inna rzecz godną jest najwyższej pochwały”, jak piękno i wspaniałość świątyni, „wzorowy porządek ceremonii”, powaga duchowieństwa i ,pobożność, z jaką kapłani spełniają święte czynności"16.

W swoim motu proprio z 22 listopada 1903 roku Papież mówi o dwóch złożonych przyczynach tychże nadużyć, z których jedne płyną $\mathrm{z}$,właściwości tej sztuki, samej w sobie chwiejnej i zmiennej"; ze zmiany u wielu ludzi (z biegiem lat) „smaku i przyzwyczajeń”; na skutek „nieszczęsnego wpływu sztuki świeckiej i teatralnej na sztukę kościelną"; ze względu na „przyjemność, którą muzyka bezpośrednio sprawia i którą nie zawsze łatwo utrzymać w odpowiednich granicach" i wreszcie ,skutkiem wielu uprzedzeń, które w tej sprawie niepostrzeżenie powstaja" ". Do drugiej grupy przyczyn, które spowodowały to jedno ,z najzwyklejszych i najtrudniejszych do wykorzenienia nadużyć", należy, w opinii papieskiej nawet „u osób poważnych i pobożnych" - uporczywe i ciągłe dążenie „do zbaczania od prostej normy ustanowionej przez cel, dla którego sztuka (muzyka) jest oddana na usługi kultu" "18. Pius X przypomina, ze ten cel muzyki i śpiewu został jasno wyrażony „w kanonach kościelnych” (tzn. w zasadach [normach] prawa Kościoła), ,w rozporządzeniach Soborów powszechnych i prowincjonalnych", a także w przepisach wielokrotnie wydawanych przez święte rzymskie Kongregacje i przez papieży. Ojciec Święty zauważa, iż wiele dobrego dokonało się w tym względzie w Rzymie i we Włoszech, ale o wiele jeszcze więcej w innych krajach,

nowy liturgicznej..., art. cyt., s. 198; Z. Z i e l i ń s k i, Papiestwo i papieże.., dz. cyt., s. 16; M. K u n z le r, Liturgia Kościota, Poznań 1999, s. 208.

${ }^{14} \mathrm{P}$ j u s X, Motu proprio Tra le sollecitudini..., dz. cyt., s. 213.

15 Tamże, s. 214 n.

16 Tamże, s. 215.

17 Tamże.

18 Tamże. 
gdzie „znakomici mężowie”, ,gorliwi o chwałę Bożą", połączyli się, za pozwoleniem Stolicy Świętej i pod kierunkiem swoich biskupów, „w kwitnące stowarzyszenia i prawie w każdym swym kościele i kaplicy przywrócili zaszczytne miejsce należne muzyce kościelnej" "19 Należy jednak „zganić i potępić wszystko to, co w świętych czynnościach i obrzędach kościelnych niezgodne jest $\mathrm{z}$ istniejącymi przepisami”20 "Najgorętszym pragnieniem" Papieża stało się, aby na powrót rozkwitł i utrzymywał się wśród wiernych ,prawdziwy duch chrześcijański”, którego wierni mogą zaczerpnąć „z najpierwszego i niezbędnego źródła, jakie stanowi czynny współudział w najświętszych tajemnicach oraz modłach publicznych i uroczystych Kościoła" "2]. "Celebracja liturgiczna i czynne w niej uczestnictwo wiernych jest więc głównym źródłem ducha chrześcijańskiego"22.

Św. Pius X uznał, iż byłoby rzeczą daremną spodziewać się „obfitego błogosławieństwa niebios", jeżeli sposób, w jaki wierni zanoszą do Boga swe błagania, „Zamiast wznosić się 'w wonności wdzięczności', wciskać Mu będzie do ręki powrozy, którymi Boski Zbawiciel wyganiał ongiś ze świątyni niegodnych, którzy ja bezcześcili"23.

Mając na uwadze wszystkie powyższe racje, a także, by ,znikła wszelka niepewność w tłumaczeniu niektórych już wydanych przepisów", Papież postanowil „wskazać w krótkości te zasady, które winny kierować muzyką kościelną w świętych obrzędach, oraz zebrać w jedną ogólną całość główne przepisy Kościoła, wydane przeciw najpospolitszym nadużyciom w tej sprawie"24.

\section{Muzyka integralna częściq liturgii}

Muzyka kościelna, w nauczaniu Piusa X w jego motu proprio z 22 listopada 1903 roku, to integralna część uroczystej liturgii, z którą dzieli cel ogólny, ,jakim jest chwała Boża, uświęcenie i zbudowanie wiernych"25. Muzyka kościelna przyczynia się także do powiększenia powagi i wspaniałości ceremonii kościelnych, a „przyodziewając” odpowiednią melodią tekst liturgiczny, dodaje mu większej siły, przyczyniając się do jego lepszego zrozumienia przez wiernych. Za pośrednictwem zatem muzyki wierni jeszcze mocniej są pobudzani do pobożności i skuteczniej usposobieni do bardziej owocnego korzystania z „owoców łaski, powstających przy sprawowaniu Przenajświętszych Tajemnic"26.

Spelniając taką ważną rolę w liturgii, muzyka kościelna powinna posiadać cechy właściwe liturgii, a mianowicie: świętość, piękno i doskonałość formy oraz

${ }^{19}$ Tamże.

${ }^{20}$ Tamże, s. 216.

${ }^{21}$ Tamże.

${ }^{22}$ B. N e u n h e u s e r, Sto lat ruchu odnowy liturgicznej..., dz. cyt., s. 198.

${ }^{23} \mathrm{P}$ i u s X, Motu proprio Tra le sollecitudini..., dz. cyt.

${ }^{24}$ Tamże.

${ }^{25}$ Sobór Watykański II, 60 lat później (4 grudnia 1963 r.), powtórzył w Konstytucji o liturgii świętej to nauczanie św. Piusa X, iż celem muzyki kościelnej jest chwała Boża i uświęcenie wiernych - por. KL 112.

${ }^{26} \mathrm{P}$ i u s X, Instrukcja o muzyce kościelnej, nr 1 (cyt. za: G. M. S u ñ o I, Zasady śpiewu..., dz. cyt., s. 216 n.). 
powszechność ${ }^{27}$. Św. Pius X był znawcą i miłośnikiem poważnej muzyki kościelnej, ubolewając, już jako młody kapłan i proboszcz, nad upadkiem śpiewów pieśni religijnych w kościołach włoskich. Dlatego jako profesor śpiewu łacińskiego gregoriańskiego w seminarium duchownym w Treviso uczył i szerzył znajomość chorału oraz zachęcał (zwłaszcza młodych kandydatów do kapłaństwa) do starannego wykonywania melodii gregoriańskich, a także przestrzegając przed rozmaitymi „,nieprawidłowościami” w muzyce i śpiewie kościelnym. Jako pasterzbiskup Kościoła Mantui (1884 r.), a później kardynał i patriarcha Wenecji (1893 r.), z wielką gorliwością pasterską troszczył się o tę, zaniedbaną wtedy, dziedzinę sztuki, która zarazem pozostaje tak ściśle związana z życiem religijnym wiernych. Wymownym świadectwem takiej troski jako patriarchy weneckiego był wystosowany do duchowieństwa i wiernych w 1895 roku list pasterski, w którym podkreślał m.in., iż śpiew i muzyka kościelna, nieodłącznie powiązane z liturgia, muszą wyróżniać się świętością, doskonałością artystyczną i powszechnością.

Muzyka kościelna powinna być święta, czyli „wykluczać wszelką świeckość" w sobie samej i w sposobie jej wykonywania przez uczestników liturgii.

Muzyka święta (musica sacra) winna być prawdziwą i doskonałą artystycznie sztuka, aby mogła skutecznie wywierać wpływ na „dusze tych, którzy jej słuchają" i to taki wpływ, ,jaki Kościół zamierza wywrzeć, przyjmując do swej liturgii sztukę tonów".

Muzyka używana w liturgii powinna mieć charakter powszechny, tzn. winna umoźliwiać każdej narodowości stosowanie w utworach kościelnych tych form, które stanowią wyłączną cechę ich muzyki. Należy jednak podporządkować te formy „ogólnym cechom muzyki kościelnej, aby nikt z innej narodowości, słuchając jej, nie doznał niedobrego wrażenia, ${ }^{, 28}$.

\section{Śiew gregoriański wzorem muzyki kościelnej}

Cechę świętości, piękna i doskonałości formy oraz powszechności posiada zdaniem Piusa X - „w najwyższym stopniu” śpiew gregoriański, który dlatego jest „śpiewem właściwym Kościoła Rzymskiego". Jest jedynym śpiewem, który Kościół odziedziczył „po ojcach dawnych” i ,którego z zazdrością strzegł przez długie wieki w swych księgach liturgicznych" i który „najnowsze studia tak szczęśliwie przywróciły do pierwotnej nieskazitelności i czystości"29.

Papież nie tylko przypomina, że śpiew gregoriański był zawsze uważany za „pierwowzór muzyki kościelnej”, ale jest zdania, iż stało się zasadą twierdzenie: „o tyle jakaś kompozycja przeznaczona dla Kościoła jest świętsza i bardziej litur giczna, o ile więcej w swym przebiegu, w swym natchnieniu i smaku zbliża się do melodii gregoriańskiej; o tyle zaś mniej jest godna świątyni, o ile więcej staje się niezgodna z tym najwyższym wzorem"30. Jest dlatego ważną sprawą przywrócenie śpiewu gregoriańskiego „w obrzędach kultu”, a zatem wśród wiernych, aby i oni

\footnotetext{
${ }^{27}$ Por. tamże, nr 2.

${ }^{28}$ Tamże.

${ }^{29}$ Tamże

${ }^{30}$ Tamże
} 
„tak jak to dawniej bywało”, znowu „bardziej czynnie uczestniczyli w nabożeństwach kościelnych"

W muzyce liturgicznej - w myśl dokumentu Piusa X z 22 listopada 1903 ro$\mathrm{ku}$ - nie może zabraknąć miejsca na tzw. „klasyczną polifonię”, która „w wysokim stopniu zbliża się do śpiewu gregoriańskiego, (...) wzoru muzyki kościelnej”. Szczególnym przykładem jest w tym względzie „szkoła rzymska”, która „w wieku XVI doszła do szczytu swej doskonałości w utworach Pierluigi da Palestrina, i która w dalszym ciągu nie przestaje wydawać dzieł doskonałych pod względem liturgicznym i muzycznym" ${ }^{2}$. Polifonia powinna być „na powrót wprowadzona do kościelnych uroczystości, szczególnie w znaczniejszych bazylikach, kościołach katedralnych, kaplicach seminariów oraz innych instytutów kościelnych",33.

Kościół dopuszcza „na usługi kultu” wszystko, co „geniusz w ciągu wieków mógł stworzyć dobrego i pięknego, z zachowaniem jednakże zawsze praw liturgii", i na tej zasadzie także muzykę współczesna, ,,skoro i ona dostarcza dzieł tak dobrych, poważnych i uroczystych, że stają się całkiem godnymi obrzędów liturgicznych" ${ }^{34}$. Trzeba jednak zwracać uwagę, aby kompozycje muzyczne w najnowszym stylu, które się dopuszcza do Kościoła, nie zawierały w sobie nic świeckiego; nie były wzorowane na utworach świeckich czy przeznaczonych do użytku świeckiego oraz nie zawierały „reminiscencji motywów wykonywanych w teatrach". Papież Pius X wyraźnie stwierdza, że najmniej odpowiednim do stosowania w obrzędach kultu jest „,styl teatralny", który ,z natury rzeczy samej staje w największym przeciwieństwie ze śpiewem gregoriańskim i z klasyczną polifonia, a tym samym występuje przeciw prawu zasadniczemu każdej dobrej muzyki kościelnej”35.

Św. Pius X, mówiąc w swoim motu proprio o ważności śpiewu gregoriańskiego, przypomniał, że językiem „właściwym” Kościoła Rzymskiego jest język łaciński i dlatego zakazał w uroczystych czynnościach liturgicznych śpiewać cokolwiek w języku ludowym. Papieskie nauczanie tak wyraźnie zalecające śpiew gregoriański w liturgii sprawiło, iż papież Pius X przez muzyków i liturgistów jest nazywany „odnowicielem” chorału gregoriańskiego.

\section{DEKRET O CZESTEJ, CODZIENNEJ KOMUNII ŚW.}

W apostolskiej posłudze papieża Piusa X centralne miejsce zajmowała Msza święta, w której czynnym uczestnictwie miała najpierw służyć reforma mszału rzymskiego. Nie udało się jednakże świętemu Papieżowi tego dokonać, poza wprowadzeniem pewnych poprawek i uzupełnień. Pius X zdołał natomiast przybliżyć wszystkim wiernym częstą Komunię św., w której codzienne uczestnictwo było w wielu częściach Kościoła uważane dotąd za praktykę bliską jakiemuś nadużyciu! ${ }^{36} \mathrm{Na}$ początku XX wieku, mimo ożywionej dyskusji pomiędzy zwolenni-

${ }^{31}$ Tamże.
${ }^{32}$ Tamże.
${ }^{33}$ Tamże.
${ }^{34}$ Tamże.
${ }^{35}$ Tamże.
${ }^{36}$ Por. R. A u be rt, Das Reformwerk Pius'X. Eucharistische.., art. cyt., s. 417 n.; Z. Z i e l i ń s k i, Papiestwo i papieze..., dz. cyt., s. 17. 
kami i przeciwnikami, nie brakowało wielu środowisk, które miały odnośnie do częstej Komunii bardzo jasny pogląd „za”. Wielką pomocą w przyjęciu takiej postawy była encyklika papieża Leona XIII Mirae caritatis $(1902)^{37}$, która zachęcała do częstego przyjmowania Eucharystii, sprzeciwiajacc się jednocześnie pozornym powodom powstrzymywania się od częstej Komunii, wysuwanym zwłaszcza we Francji i Belgii. Wielkim zwolennikiem, określanym nawet „heroldem” częstej Komunii świętej, stał się we Francji ksiądz de Ségur, który uzasadniał, że Komunia nie stanowi nagrody za zdobyte cnoty, lecz przeciwnie, jest środkiem do ich osiagnięcia! W publikacji La très sainte communion, która wbrew oporowi starszych duchownych, stała się bardzo poczytną (była tłumaczona na obce języki), zalecał przyjmowanie Komunii co tydzień, a nawet co drugi dzień lub też codziennie $^{38}$. Postawę częstego przyjmowania Komunii św. bardzo mocno popierał rzymski kardynał Gennari oraz biskup Namur, Heylen, wielokrotny przewodniczący stałego Komitetu międzynarodowych Kongresów Eucharystycznych. Wielu zwolenników tej postawy eucharystycznej można było znaleźć nie tylko w całych Włoszech, a także i poza jej granicami, zwłaszcza na północ od Alp, a ponadto pośród duchowieństwa zakonnego, w tym szczególnie pośród jezuitów ${ }^{39}$. Kiedy zaś Don Giovanni Bosco, gorliwy obrońca częstej Komunii i wczesnej Komunii dzieci, wspaniale rozwijal te praktyki eucharystyczne, podziwiany przez niego ks. Giuseppe Sarto zostając biskupem uczynił rozwój tychże praktyk najważniejszym punktem swego programu duszpasterskiego. Dlatego nic dziwnego, że kiedy został wybrany papieżem, zatroszczył się o to, by ten program urzeczywistnić w całym Kościele. Na przestrzeni tylko dwóch lat, od 30 maja 1905 r. do 14 lipca 1907 r., papież Pius X dwanaście razy, poprzez dekrety, listy i przemówienia, zwracał uwagę wszystkich na ten problem ${ }^{40}$. W upowszechnieniu praktyki częstej Komunii bardzo wiele pomógł odbywający się w Rzymie, pod przewodnictwem wikariusza Rzymu kardynała Respighiego i przewodniczącego stałego Komitetu biskupa Heylena, w dniach 1-4 czerwca 1905 roku, XVI Międzynarodowy Kongres Eucharystyczny, w którym po raz pierwszy uczestniczył papież, właśnie św. Pius $\mathrm{X}$, który też poprowadził, w bazylice św. Piotra, procesję na zakończenie Kongresu. Jednym ze szczególnie ważnych tematów różnych spotkań kongresowych była sprawa częstej, a nawet codziennej Komunii świętej wiernych ${ }^{41}$. $\mathrm{Z}$ okazji tego Kongresu Pius X zaaprobował i zezwolił na rozpowszechnianie modlitwy „, o rozszerzanie się pobożnego zwyczaju codziennej Komunii", w której zostało przy-

${ }^{37}$ Zob. AAS 34(1901/2), s. 641-644; por. R. A u bert, Das Reformwerk Pius'X. Eucharistische..., art. cyt., s. 416; por. M. B a n a s z a k, Historia Kościoła..., dz. cyt., s. 375.

${ }^{38}$ Zob. R. A u be r t, Das Reformwerk Pius'X..., dz. cyt., s. 417; M. B a n a s a k, Histo-

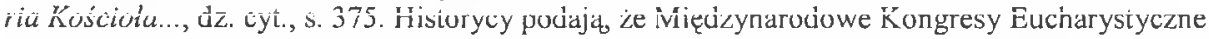
(pierwszy odbył się we Francji, w Lille, w 1881 roku) zrodziły się z prywatnej pobożności Marii Tamisier, która otrzymała potrzebne „wsparcie” i aprobatę m.in. od biskupa de Ségur z Paryża, biskupa Mermilloda z Fryburga i biskupa Doutreloux z Lüttich (zob. J. F. C h o r o s z y, Z. J a r o s z e k, Międzynarodowe Kongresy Eucharystyczne, Wrocław 1997, s. 12).

${ }^{39}$ Spośród jezuitów wymienia się nazwisko francuskiego jezuity P. L. Crosa, który żył i działał w Hiszpanii, a który nie za bardzo troszcząc się o opory tamtejszej hierarchii, z entuzjazmem rozwijał „czteropunktowy” program: comulgar (komunikować), cada dia (codziennie), sin confesarse (bez spowiadania się) i hasta la muerte (aż do śmierci) (zob. R. A u b e r t, Das Reformwerk Pius'X. Eucharistische..., art. cyt., s. 417).

${ }^{40}$ Por. R. A u b e r t, Das Reformwerk.., dz. cyt., s. 417

${ }^{41}$ Por. J. F. Ch or o s z y, Z. J a ros z e k, Międzynarodowe Kongresy..., dz. cyt., s. 45 n. 
pomniane, że Jezus chciał być „codziennym lekarstwem i codziennym pokarmem naszej codziennej słabości” ${ }^{\text {"42 }}$. Decydującym zaś dokumentem stał się dekret Kongregacji soborowej Sacra Tridentina Synodus (ogłoszony na polecenie Papieża 20 grudnia 1905 roku) O codziennym przyjmowaniu Komunii świętej - De quotidiana SS. Eucharistiae sumptione $e^{43}$, który w kontekście trwających dyskusji i sporów przynosił uzasadnienie teologiczne oraz konkretne przepisy praktyczne (były to decydujące rozstrzygnięcia), precyzujące np. dwa warunki, których spełnienie jest konieczne do przyjęcia Komunii, a mianowicie: stan laski (wolność od grzechu ciężkiego) i prawdziwą intencję. Dekret odwoływał się do nauczania Chrystusa ${ }^{44}$, który stał się codziennym pokarmem dla swoich uczniów, zapewniając ich, iż „kto spożywa ten chleb, będzie żył na wieki" (J 6,51.58) i który nakazał im w modlitwie Ojcze nasz prosić o ,chleb powszedni”, rozumiany przez Ojców Kościoła jako przede wszystkim chleb eucharystyczny ${ }^{45}$. Za Soborem Trydenckim dekret przypominal, iż Boski Zbawiciel, „mając odejść z tego świata do Ojca, ustanowił Sakrament, w którym niejako wylał skarby swojej Boskiej milości ku ludziom, 'czyniąc pamiątkę cudów swoich' (Ps 110,4). (...) Chcial zaś, by ten Sakrament byl przyjmowany jako duchowy pokarm dusz (Mt 26, 26), które by się nim karmiły i umacniały, żyjąc życiem Tego, który powiedział: 'Kto mnie pożywa, żyć będzie dla mnie' (J 6, 58), i jako środek zaradczy uwalniający nas od powszednich grzechów i chroniący przed ciężkimi. Chciał nadto, żeby ten sakrament był zadatkiem naszej przyszłej chwały i wiecznej szczęśliwości" ${ }^{46}$. Mając na uwadze to nauczanie Kościoła, dekret z 1905 roku wyrażał ponadto życzenie, aby „podczas każdej Mszy św. obecni wierni komunikowali nie tylko duchowym uczuciem, lecz także sakramentalnym przyjęciem Eucharystii, ażeby dostapić obfitszych owoców tej Najświętszej Ofiary"47. Kościól, w polecanym przez św. papieża Piusa X dekrecie Sacra Tridentina Synodus, zachęcał wiernych, aby przystępowali do Komunii „,bardzo często, a nawet codziennie”, ponieważ ,jasną jest rzeczą że przez częste lub codzienne przyjmowanie Najświętszego Sakramentu zwiększa się zjednoczenie z Chrystusem, życie duchowe otrzymuje obfitszy pokarm, dusza bardziej wzbogaca się cnotami, a przyjmujący otrzymuje w sposób pewniejszy zadatek wiecznej szczęśliwości, dlatego proboszczowie, spowiednicy i kaznodzieje niech zachęcają chrześcijański lud do tak zbożnej i zbawiennej praktyki częstymi napomnieniami i $z$ wielką gorliwością, ${ }^{38}$.

${ }^{42}$ Zob. R. A u b e r t, Das Reformwerk Pius'X. Eucharistische..., art. cyt., s. 417.

${ }^{43}$ Zob. AAS (1910), s. 894-898; por. G. C a s t e 11 a, J. V ill i g e r, Papstgeschichte. III, Zürich 1966, s. 147; A. H a qu i n, Les décrets eucharistiques de Pie X..., art. cyt., s. 66.

${ }^{44}$ Por. rozdział VI Ewangelii według św. Jana (cudowne rozmnożenie chleba i mowa eucharystyczna).

${ }^{45}$ Zob. A. H a qu in, Les décrets eucharistiques de Pie X.., art. cyt., s. 66.

${ }^{46}$ Zob. Sobór Trydencki. Sesja XIII. Dekret o Najświętszym Sakramencie (1551), rozd. II (zob. Breviarium fidei. Wybór doktrynalnych wypowiedzi Kościola, Poznań 1998, s. 400).

${ }^{47}$ Sobór Trydencki. Sesja XXII (1562), rozd. VI (zob. Breviarium fidei..., dz. cyt., s. 414). W tłumaczeniu dosłownym tekst soborowy brzmi: ,aby podczas każdej Mszy św. wierni, którzy w niej uczestnicza, nie zadowalali się komunikowaniem duchowym, lecz by także przyjmowali z niej Komunię (Eucharystię) sakramentalnie" (zob. A. H a q u i n, Les décrets..., art. cyt., s. 66).

${ }^{48}$ Cyt. za: Kongregacja Obrzędów, Instrukcja Eucharisticum mysterium (25 V 1967), nr 37 - zob. J. Miazek (oprac.), To czyńcie na moja pamiatkę. Eucharystia w dokumentach Kościola, Warszawa 1987, s. 177 n.). 
Rozporządzeniem papieża Piusa X dekret ten został wysłany do wszystkich biskupów i przełożonych zakonnych z poleceniem przekazania go swoim seminariom duchownym, proboszczom, instytutom zakonnym i wszystkim prezbiterom, a potem zawiadomienia Stolicy Świętej o podjętych działaniach dla zrealizowania postanowień dekretu ${ }^{49}$. W ciagu następnych miesięcy wydawane nowe dekrety jeszcze bardziej zachęcały wiernych do częstego udziału w Komunii świętej, czy to poprzez udzielenie odpustów (14 XII 1906), czy też przez dyspensę zezwalającą chorym (dłużej niż miesiąc leżącym w łóżku) na przyjmowanie Komunii bez konieczności zachowania postu eucharystycznego ( 7 XII 1906 i 6 III 1907). Owe dekrety precyzowały ponadto, iż stosowane w tekście sformułowanie „wszyscy wierni" obejmuje także dzieci, które przystapiły już do pierwszej Komunii św. (13 IX 1906$)^{50}$.

\section{WCZESNA, PIERWSZA KOMUNIA ŚW. DZIECI (1910)}

Od pierwszych wieków chrześcijaństwa udzielanie Komunii wiernym miało miejsce najpierw $w$ ramach sakramentów wtajemniczenia chrześcijańskiego: chrztu, bierzmowania i Eucharystii. Zwyczaj ten był praktykowany w Kościele Zachodu do wieku XI/XII, kiedy pojawiła się praktyka udzielania tych trzech sakramentów rozdzielnie, w różnym czasie. Od wieku XIII przyjęto zwyczaj udzielania Komunii dzieciom indywidualnie, ale bez specjalnie wyróżniającej uroczystości, i razem z innymi wiernymi. Zobowiązanie przez Sobór Laterański IV w roku 1215 wszystkich wiernych do przyjmowania Komunii raz w roku w czasie wielkanocnym sprawiło, że właśnie w tym okresie roku liturgicznego odbywała się (najczęściej) Komunia dzieci. W wiekach XVI-XVIII ustala się, różnie w wielu Kościołach lokalnych, rok życia uprawniajacy do przyjmowania Komunii św. przez dzieci; jego ,rozpiętość” była stosunkowo duża, bo od siódmego do 13-14 roku życia, czy nawet, pod wpływem jansenizmu, do $15-19$ roku życia $^{51}$. Na wiek przyjęcia pierwszej Komunii wplynął ponadto wprowadzany obowiązek uczęszczania dzieci do szkoły i związana z tym troska o wychowanie religijne zwłaszcza w szkołach prowadzonych przez Kościół. Powstał zwyczaj (głównie we Francji, Belgii, Holandii i Niemczech) uroczystej Komunii wielu dzieci i specjalnego do niej przygotowania, który łączono niekiedy z ukończeniem szkoły. W drugiej połowie XIX wieku i na początku XX wieku, pod wpływem rozwijają-

\footnotetext{
${ }^{49}$ Por. R. A u b e r t, Das Reformwerk Pius' X. Eucharistische.., art. cyt., s. 418.

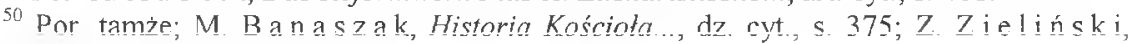
Papiestwo i papieże..., dz. cyt., s. 17.

${ }^{51}$ Zob. B. N a d o ls k i, Liturgika, IV: Eucharystia, Poznań 1992, s. 85. Jansenizm (nazwa pochodzi od nazwiska Corneliusa Jansena [łac.: Jansenius, $\uparrow 1638$ ], profesora teologii w Lovanium, później biskupa diecezji Ypres) był przede wszystkim nurtem teologicznym, podkreślającym m.in. pesymistyczny pogląd na ludzką naturę, skażenie człowieka przez grzech pierworodny, niegodność człowieka, konieczność surowej ascezy i moc łaski Bożej. Jansenizm był też pewnym stylem życia duchowego i pobożności, pesymistyczny w poglądzie na czlowieka, surowy w wymaganiach ascetycznych, oszczędny w praktykach sakramentalnych, a zwłaszcza niechętny częstej Komunii świętej, której człowiek stale jest nie dość godny - zob. W. Ł y d k a, D. O I s zew s k i, Jansenizm, [w:] A. Z u be r bi e r (red.), Stownik teologiczny, Katowice 1998 , s. 214 n.
} 
cego się ruchu liturgicznego, problem pierwszej Komunii dzieci, a właściwie roku życia (wieku), w którym miałyby one do niej przystappić, powrócił i budził nadal kontrowersje, które ustały, gdy został wydany po licznych konsultacjach i zaaprobowany przez papieża Piusa X, 8 sierpnia 1910 roku, dekret Kongregacji Sakramentów Quam singulari Christus amore ${ }^{52}$. Kościół wyjaśniał w tym dekrecie problematykę ,pierwszokomunijną" w wymiarze historycznym, dogmatycznym i pastoralnym, postanawiając jednocześnie, iż dzieci mogą przyjmować Komunię święta od chwili zyskania pełnego rozeznania, czyli gdy będą potrafiły odróżnić chleb eucharystyczny od zwykłego chleba „powszedniego" oraz gdy posiąda znajomość najbardziej podstawowych prawd wiary, co ma miejsce około 7-8 roku życia dziecka ${ }^{53}$. Dekret potwierdzał tym samym, iż nie trzeba zatem czekać z pierwszą Komunią do 10,12 czy 14 roku życia, jak to często dotychczas praktykowano. Takie spojrzenie Kościoła oznaczało nowe zastosowanie zasady, na której opierała się cała eucharystyczna reforma papieża Piusa X, iż mianowicie Komunia święta jest nie tyle nagrodą za dobre, zgodne z wolą Bożą życie chrześcijanina, ale o wiele istotniejsza jest jej działająca moc jako „pokarmu duchowego", zgodnie $\mathrm{z}$ teologiczna zasada ex opere operato ${ }^{54}$.

Rodzice, nauczyciele, spowiednicy i duszpasterze zostali zobowiązani, aby mając na uwadze niewinność dzieci i miłość Chrystusa do nich, wcześnie i często prowadzili je do Komunii świętej ${ }^{55}$. Dekret Papieża i Stolicy Apostolskiej wychodził naprzeciw nie tylko czcigodnej starochrześcijańskiej tradycji eucharystycznej w tym wzgledzie, ale i zwyczajom wiernie zachowywanym w wielu wspólnotach kościelnych. I mimo że dekret Stolicy Apostolskiej (i papieża Piusa X) nie przerwał różnych dyskusji i nie obalił od razu całkowicie starych nawyków, to jednak został przez ogół biskupów oraz wiernych w całym Kościele przyjęty z radosną wdzięcznością i gorliwie wprowadzany w życie, stanowiąc wspaniałą drogę do umacniania i pogłębiania życia religijnego w rodzinach katolickich ${ }^{56}$.

Postanowienia Piusa X wyrażone w obu dekretach: o częstej i wczesnej Komunii znalazły entuzjastyczne poparcie także w tworzonych grupach, ligach i stowarzyszeniach, jak np. w utworzonej przez ojców „od Najświętszego Sakramentu” (eucharystianie) w Rzymie (jeszcze w kwietniu 1905 roku) Lidze Kapłanów. Jako cel postawili sobie oni zachęcanie wszystkich wiernych do stosowania w życiu parafialnym dekretu o częstej Komunii; po sześciu latach Liga liczyła ponad 50 tysięcy kapłanów ${ }^{57}$. W stolicy chrześcijaństwa, bezpośrednio po wydaniu dekretu

${ }^{52}$ Zob. AAS 2(1910), s. 577-583. R. Aubert w odróżnieniu od innych historyków podaje datę 8 X 1910 jako czas wydania dekretu Quam singulari - zob. R. A u b e r t, Das Reformwerk Pius'X. Eucharistische..., art. cyt., s. 418.

${ }_{53}^{5}$ Por. G. Cast e l I a, J. Vill i g e r, Papstgeschichte. III..., dz. cyt., s. 148.

${ }^{54}$ Zob. R. A u b e r t, Das Reformwerk Pius'X. Eucharistische..., art. cyt., s. 418

${ }_{56}^{55}$ Por. G. Cast e ll a, J. V ill i g e r, Papstgeschichte. III.., dz. cyt., s. 148.

${ }^{56}$ Zob. tamże; por. Z. Z i e li ń s k i, Papiestwo i papieże..., dz. cyt., s. 17. B. Nadolski twierdzi, że omawiany tu dekret z 1910 roku przyczynił się do rozwoju Mszy ,pierwszokomunijnych" i pomnożenia zwyczajów związanych z dniem Komunii, a więc: procesji wprowadzających, przemówień bezpośrednio przed Komunia, nabożeństw popołudniowych, odnowień przyrzeczeń chrztu świętego (nawiązanie do sakramentów wtajemniczenia chrześcijańskiego), odpowiednich ubiorów, świec komunijnych, specjalnych obrazków, różnych podarków itp. zob. B. N a d o l s k i, Liturgika, IV..., dz. cyt., s. 85.

${ }^{57}$ Zob. R. A u b e rt, Das Reformwerk Pius'X. Eucharistische..., art. cyt., s. 418. 
Quam singulari (1910) powstało „Pobożne stowarzyszenie dla Komunii świętej dzieci", do którego przyłączyły się wkrótce narodowe stowarzyszenia Włoch, Hiszpanii, Belgii, Ameryki Południowej, Stanów Zjednoczonych i Kanady. Papież Pius X już w 1907 roku domagał się odprawiania dorocznego triduum eucharystycznego w każdej diecezji i możliwie w każdej parafii, aby jednocześnie bardziej jeszcze zwrócić uwagę duchowieństwa i wiennych na znaczenie dekretu z 1905 roku $^{58}$. Uzasadnienie teologiczne i nowe przepisy oraz wskazania duszpasterskie dekretu o częstej Komunii zrodzily w Belgii niezwykłą działalność „,apostoła częstej Komunii”, jezuity Julesa Lintelo (1862-1919) założyciela „Ligi Najświętszego Serca" (Pana Jezusa), której członkowie zobowiązywali się do regularnego przyjmowania Komunii ${ }^{59}$.

Pius X od początku swego pontyfikatu ,wykorzystywał” międzynarodowe Kongresy Eucharystyczne do rozpowszechniania tych dekretów, które zwłaszcza zachęcały do częstej, a nawet codziennej Komunii; w ten sposób kongresy eucharystyczne zostały ubogacone o nowy wymiar dodany do dotychczasowego aspektu skupiającego się głównie na zamanifestowaniu wiary w obecność Chrystusa Pana w Najświętszym Sakramencie i publicznym oddaniu Mu czci. Wielki orędownik częstej Komunii, J. Lintelo, poczynając od Kongresu w Metz w 1907 roku, stał się opatrznościowym mówcą propagującym na kolejnych Kongresach częstą i wczesną Komunię święta. Na XXII Międzynarodowym Kongresie Eucharystycznym, który odbywal się w Madrycie, w dniach od 23 czerwca do 1 lipca 1911 roku, kilka miesięcy po wydaniu dekretu Quam singulari, Lintelo przedstawił ideę krucjaty eucharystycznej dzieci, która przyjęto na kongresie w Lourdes, w 1914 roku i która w ciagu następnych dwóch lat została wprowadzona w 54 krajach $^{60}$.

\section{REFORMA BREWIARZA - OFFICIUM DIVINUM (1911)}

Papież Pius X podjął biblijną i liturgiczną reformę brewiarza, która stanowiła już temat Soboru Watykańskiego I, postanawiając przeprowadzić ją nie tyle w wymiarze historycznym, ile bardziej ogarniając bogaty aspekt duszpasterski, aby uwzględnić przy tym liczne prośby kierowane w tej sprawie do Rzymu z całego świata ${ }^{61}$. W odpowiedzi zatem na te liczne głosy domagające się nowego wydania brewiarza, papież powołał w tym celu, w dniu 2 lipca 1911 roku, komisję do przeprowadzenia tej reformy, która miała pracować niezależnie od Kongregacji Obrzędów i od komisji historycznej, powolanej jeszcze przez papieża Leona XIII. Przewodniczącym tej papieskiej komisji został nowy sekretarz Kongregacji Obrzędów, C. La Fontaine, duszpasterz i liturgista, który jednakże w mniejszym stopniu znał złożoną historię i rozwój róznych rzeczywistości liturgicznych. K̄o-

${ }^{58}$ Por. R. A u be rt, Das Reformwerk Pius'X. Eucharistische..., art. cyt., 419; M. B a n a s z a k, Historia Kościola..., dz. cyt., s. 376.

${ }^{59}$ Por. tamże. Podobne Ligi, choć pod różnymi nazwami, powstały we Francji i Anglii.

${ }^{60}$ Zob. R. A u bert, Das Reformwerk Pius'X. Eucharistische..., art. cyt., s. 419 n.; M. B a n a s z a k, Historia Kościoła..., dz. cyt., s. 376.

${ }^{61}$ Historycy wymieniają najbardziej reprezentatywne wystapienia w tej materii profesora liturgiki P. Piacenza, opata benedyktyńskiego Dom Guépin, Msgr. Isoard oraz publikacje w niemieckich czasopismach teologicznych: „Pastor bonus”, „Theologie und Glaube”, „Der Katholik" - zob. R. A u b e r t, Das Reformwerk..., dz. cyt., s. 424. 
misja w krótkim czasie intensywnej pracy wypełniła zlecone jej zadanie i przygotowała bogaty materiał, który pozwolił Piusowi X na wydanie motu proprio (konstytucji apostolskiej) Divino afflatu dnia 11 listopada 1911 roku ${ }^{62}$. Papież wprowadził nowy Ordo psalmorum (układ psalmów) w brewiarzu - officium divinum (dzisiejszej Liturgii godzin - codziennej modlitwie Ludu Bożego), rozdzielając sto pięćdziesiąt psalmów, w odpowiednich proporcjach na poszczególne godziny oficjum, do odmawiania w ciagu tygodnia. Dla osiagnięcia tego celu obniżono stopień obchodu wspomnień świętych, aby umożliwić odmawianie psalmów wyznaczonych w brewiarzu na dni powszednie, a nie powtarzać (skoro należało według kalendarza odmawiać wciąż oficjum świętych) przez cały rok dwadzieścia do trzydziestu tych samych psalmów znajdujących się w Commune Sanctorum. Pius $\mathrm{X}$, kierując się w swej reformie racjami pastoralnymi, brał pod uwage wieloraką pracę duszpasterską kapłanów i wypływające stąd różne trudności, i dlatego znacznie skrócił ilość i długość psalmów w poszczególnych godzinach oficjum dnia. Matutinum otrzymało dziewięć psalmów zamiast dotychczasowych osiemnastu w niedzielę i dwunastu psalmów w inne dni tygodnia; Laudesom przydzielono cztery psalmy i kantyk; Nieszpory tworzyło pięć psalmów, a pozostałe tzw. „godziny mniejsze" (prima, tertia, sexta, nona, completorium) otrzymały po trzy psalmy ${ }^{63}$.

Wprowadzając nowy rozkład psalmów w tygodniu, Divino afflatu sprowadziło wiele wspomnień świętych do tzw. rytu prostego, aby oficjum codzienne (ferialne) nie było zbyt często opuszczane. Ponadto $z$ pietyzmem zostało ułożone oficjum niedzieli, jako najważniejszego dnia w tygodniu, i tym samym zostało podniesione znaczenie niedzieli w wymiarze całego roku kościelnego.

Papież Pius X dokonując odnowy brewiarza, którą określił jako primum gradum ad Romani breviarii et missalis emendationem, zapowiadal w motu proprio Abhinc duos annos (z 23 X 1913) dalszy ciag reform w odniesieniu do czytań biblijnych, tak by odczytać w ciągu roku jak największą ilość ksiag Pisma Świętego (lectio de feria - de scriptura occurente) oraz w odniesieniu do czytań hagiograficznych, by wyeliminować spośród nich czytania apokryficzne. Zapowiadana reforma miałaby dotyczyć także homilii i uproszczenia rubryk. Zrealizowanie tych zamierzeń miało następować stopniowo, ale wskutek śmierci Papieża (20 sierpnia 1914) i wybuchu I wojny światowej nie udało się ich przeprowadzić ${ }^{64}$.

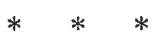

${ }^{62}$ Zob. M. R ig het t i, Storia liturgica II. L'Anno liturgico. Il Breviario, Milano ${ }^{3} 1969$, 688. Autor jako datę wydania tego dokumentu podaje 11 listopada, podczas, gdy większość „późniejszych” autorów podaje datę 1 listopada. Ponadto, jedynie M. Righetti podaje nazwiska członków tej Komisji, którą tworzyli: La Fontaine, późniejszy kardynał i patriarcha Wenecji, Pietro Piacenza, Aristide Gasparri, Scipione Tecchi, G. Bressan, P. Fonck SJ, G. D'Isengard, F. Brehm. Wyjątkowo „czynny” w tej Komisji P. Piacenza opublikował najpierw ważny komentarz na temat przeprowadzonej przez Piusa X reformy brewiarza pt.: In constitutionem „Divino afflatu" commentarium, Roma 1912, a potem siedem Epistulae apologeticae w obronie tejże reformy (zob. tamze).

${ }^{63}$ Zob. j. W., 689.

${ }^{64}$ Por. J. W i e r u s z-K ow a l s k i, Liturgika, Warszawa 1956, s. 426; B. N a d ol s k i, Liturgika, II: Liturgia i czas, Poznań 1991, s. 197. 
Św. Pius X zgodnie z przesłaniem swego pontyfikatu „odnowienia wszystkiego w Chrystusie" (instaurare omnia in Christo) dokonał przede wszystkim odnowienia liturgii, zwłaszcza w odniesieniu do Mszy świętej oraz ściśle z nią zwiazanego wczesnego i częstego uczestnictwa wiernych w Komunii świętej. Odnowę liturgiczną rozpoczął Papież od reformy muzyki kościelnej i śpiewu, określając ich miejsce w liturgii jako jej integralną część, a nie przypadkową ozdoba. Dlatego dążył do wyeliminowania $z$ liturgii muzyki i śpiewu o cechach teatralności, opery i świeckości, polecając czerpanie treści i formy z chorału gregoriańskiego oraz rozpowszechnianie klasycznej polifonii, podkreślając zdecydowanie, że muzyka oraz śpiew w liturgii muszą zachować charakter religijny i artystyczny. Papież Pius $\mathrm{X}$ w podjętej odnowie liturgii nie ograniczal się do spraw tylko formalnych, ale przybliżał wszystkim wiernym liturgię jako uobecnianie zbawczego dzieła Jezusa Chrystusa w tym celu, aby mogli oni w niej czynnie uczestniczyć. Temu też celowi służyła odnowa brewiarza, w którym dokonano potrzebnych poprawek, zwłaszcza w obchodzie wspomnień świętych i uzupełnień, wprowadzając nowy rozkład psalmów. Papież uczynił to wszystko po to, aby modlitwę brewiarzową jeszcze bardziej powiązać z codzienną liturgia, aby wierni mogli zaczerpnąć „ducha prawdziwie chrześcijańskiego" „, najpierwszego i niezbędnego źródła, jaki stanowi czynny wspóludział w najświętszych tajemnicach oraz modlitwach publicznych i uroczystych Kościoła"

${ }^{65} \mathrm{P}$ i u s X, Motu proprio Tra le sollecitudini.., dz. cyt., s. 216. 


\section{Instaurare omnia in Christo des Papstes Pius' X. (1903-1914) und die liturgische Erneuerung Zusammenfassung}

Papst Pius X. (1903-1914) hat sein Pontifikat, das unter dem Motto Instaurare omnia in Christo („Alles in Christo erneuern") stand, mit der Erneuerung der Liturgie angefangen. Bei seinem eifrigen Streben, Kirche und Menscheit durch wiederbelebung der Frömmigkeit zu erneuern, war Pius X. auch um die Reinheit und Erhabenheit der gottesdienstlichen Formen besorgt. Seine Reformen auf diesem Gebiet bezogen sich zunächst auf die kirchliche Musik, die damals besonders in Italien verweltlicht und entartet war. Das Motu proprio Tra le sollecitudini vom 22. November 1903 (Fest der heiligen Cäcilia) (das sich direkt auf die Kirchenmusik bezog), sollte nach Pius'X. eigenen Worten ein Grundbuch der Kirchenmusik sein. Unter seinen Hirtensorgen, so führt der Papst aus, rage diejenige für die Würde des Gotteshauses hervor, in dem sich die Gläubigen zur Feier der Geheimnisse und Verrichtung ihrer Gebete versammeln und also nichts geschehen dürfe, was ihre Frömmigkeit stören und die Heiligkeit des Ortes beleidigen könnte, wie dies die kirchenmusikalischen Abwege und Missbräuche unter dem Einfluss der profanen Kunst zu tun drohten. Die Kirchenmusik müsse als integraler Bestandteil der Liturgie die Ehre Gottes und die Andacht der Zuhörer fördern und daher heilig, universell und künstlerisch sein.

Von besonderer Bedeutung sind im Werke des grossen Seelsorgepapstes die Kommunionerlasse. Im Dekret der Konzilskongregation vom 20. Dezember 1905 erklärte Pius X. als Wunsch Christi und der Kirche, dass alle Gläubigen öfters, ja möglichst jeden Tag in würdiger Weise zum heiligen Mahle gehen möchten, um durch die eucharistische Vereinigung mit Gott als Heilmittel gegen ihre Gebrechen, nicht etwa als Lohn für ihre Tugenden, die Kraft zur Stärkung der Liebe zu gewinnen. Am 8. August 1910 erklärte die Sakramentskongregation mit ausführlicher dogmatischer Begründung und päpstlicher Bestätigung, es genüge zur ersten heiligen Kommunion, dass ein Kind zu denken anfange und hinreichende Vernunft aufweise, um das eucharistische Brot von gewöhnlichen Speisen zu unterscheiden und die notwendigen Glaubensstücke zu begreifen, was ungefähr im siebten Lebensjahr der Fall sei.

Pius ' $X$. liturgische Reformen beschränkten sich nicht nur auf die Kirchenmusik und die Kommunionerlasse; sie betrafen auch das kirchliche Gebet als solches. Die Konstitution vom 11. November 1911 und das Motu proprio vom 23. Oktober 1913 führen die schon von früheren Päpsten unternommenen Reformen des römischen Breviers weiter. Die alte Sitte der Verrichtung des ganzen Psalteriums soll erneuert, zugleich der Kirchenkalender von der Überwucherung mit Heiligenfesten gereinigt und angesichts der vielfach starken Belastung des Seelsorgeklerus eine Kürzung der Offizien durch eine neue Verteilung der Psalmen vorgenommen werden.

Pius X. hat die Liturgie als die „erste und unersetzliche Quelle für den wahren christlichen Geist" proklamiert und die aktive Teilnahme der Gläubigen an ihr gefordert. 